\title{
Benchmarking in human resource management in focus of Central and Eastern Europe in the light of CRANET research
}

\author{
József Poór
}

Selye János University, Komarno, Slovakia

Agneš Slavić

University of Novi Sad Faculty of Economics Subotica, Subotica, Serbia

Tóth Katalin

Szent István University, Gödöllö, Hungary

Nemanja Berber

University of Novi Sad Faculty of Economics Subotica, Subotica, Serbia

\section{Kinga Kerekes}

Babes-Bolyai University Cluj-Napoca, Romania

\section{Zsuzsa Karoliny}

University of Pécs Faculty of Business and Economics, Pécs, Hungary

\begin{abstract}
In the Central and Eastern European (CEE) countries within the framework of the previous economic system, there were only traces of the features of modern human resource management (HRM). Since the political and economic changes, major transformation in the HRM practice has occurred, resulting in a development of the organizational position, role and practices of HR activity in the Central and Eastern European countries.

The aim of our benchmark study is to compare the HRM practice of the CEE region with the other European countries and with the global HRM trends. The benchmarking study may show the region-specific characteristics of HRM practice in the CEE region. The comparison of specific HR variables (availability of HR departments and HR services, strategic importance of HR functions, budget of training and development, influences of Trade Unions) will be made based on the data of Cranet international research results from 2004 to 2016.
\end{abstract}

Keywords

Human resource management, Central and Eastern Europe, Cranet, benchmarking

\section{Introduction}

Human capital and their skills are the main drivers of economic growth and national competitiveness in the modern economy (Kordić \& Milićević, 2018; Radivojević, Kahrović \& Krstić 2019), “they introduce changes and innovations, they create additional value and they increase business efficiency, and thus the initiation of future organization performance" (Perić, Gašić,
Stojiljković \& Nešić, 2018, p. 618). Also, in the era of automation and digitalization, it is important to develop human capital in a firm to make them capable to handle new challenges (Nica, 2018; Stuken \& Korzhova, 2019). The working arrangements have been changed a lot (Popescu, 2018) and new knowledge, skills, and abilities are needed, in terms of problem solving, critical thinking, creativity, people management, coordinating with others, emotional intelligence, 
judgment and decision-making (Héder, Szabó \& Dajnoki, 2018, p. 130).

In Central and Eastern European (CEE) countries within the framework of the previous economic system, there were only traces of the features of modern human resource management (HRM). Since the political and economic changes, major transformation in the HRM practice has occurred, resulting in a development of the organizational position, role and practices of HR activity in the Central and Eastern European countries.

The aim of our benchmark study is to compare the HRM practice of the CEE region with the other European countries and with the global HRM trends. The comparison of specific HR variables (availability of HR departments and HR services, strategic importance of HR functions, budget of training and development, influences of Trade Unions) is based on the data of Cranet international research results from 2004 to 2016.

This paper consists of four parts. In the first part, the authors presented the main features of the HRM practice in the CEE region and the importance of benchmarking studies in this area. In the second part there has been presented the methodology of the research. In the third part the authors presented the main results of the analysis of the data. At the end, there are given some concluding remarks based on the research.

\section{Theoretical background}

In different regions of the world, in different forms of capitalism (coordinated or free-market capitalism), different HRM approaches and practices have emerged due to the significant differences observed above, which are further diminished by the institutional and cultural characteristics of each country (Armstrong \& Taylor, 2017). These features also explain the contextual nature of HRM, which is dependent on environmental conditions. This is why we consider it legitimate to examine the practice of transforming countries separately (Mathias Jackson, Valentine \& Meglich, 2017).

In studying the traditional and recent forms of comparative capitalism, four different models are distinguished by different authors:

1. Two traditional forms of different systems of capitalism are as follows. The free market is a large-scale Anglo-Saxon Liberal Market Economies (shareholder capitalism) and Coordinated Market
Economies (stakeholder capitalism) (Hall and Soskice 2001; Whitley, 1999; Amable, 2003).

2. The group of Southern and Latin countries is the third group so called Mediterranean or Mixed Market Economies (Hancke, Rhodes \& Thatcher, 2007)

3. Emerging Market Economies of Central and Eastern Europe (CEEs) (Amable, 2003; Brewster et al., 2010; Poctowski, 2011; Kazlakauiste et al., 2013).

In the following section, we will only deal with the fourth group of countries mentioned above; some of typical characteristics of HR are summarized below.

From the point of view of human resource management, the management of the Eastern European Country cluster (CEE) as a separate cluster can be explained by the following in the literature. Due to the traditions, the level of economic development of each single country and the different centralization of the previous economic and political system, differences in development can be observed in the HRM practice of the various Central and Eastern European countries (Erutku \& Vallee, 1997; Poór 2008).

In these countries within the framework of the previous system, there were only traces of the features of modern HRM (Brewster, Morley \& Buciuniene, 2010, Pocztowski, 2011). In most cases, there were some approaches to the science management method. The human resource management function was largely over politicized in the case of "white-collar jobs" (Morley, Poór, Heraty, Alas \& Pocztowski, 2016). The key positions in companies were closely monitored by the party and by state bureaucracy. Management was not considered as a profession (Cakrt, 1993) and decisions regarding promotion were not based on performance assessment (Pearce, 1991).

Since the change of regime, major changes in human resource management have taken place. Ownership structure has been transformed in these countries. The dominance of state and cooperative property has ceased, large foreign capital has flown into the region in a form of FDI, as an ,external source of accumulation and indisputable precondition of permanent change of economic growth to a higher level" (Cvetanović Despotović \& Milovanović, 2018, p. 18). Also, “current globalization process, internationaliza-tion of political, economic and social ties, development of technology, raising environmental awareness, are constantly imposing the need to adapt to a turbulent 
environment" (Slavković \& Slavković, 2019, p. 116), where HRM is also changing and adapting. It has been a constant problem what HRM practice would be the best. Especially in the case of local subsidiaries of multinational companies, significant changes could be observed. According to Lewis (2005), these companies have redefined the map of the labor market of the former socialist countries in many respects. Thus, among others, they have pulled down equation and introduced the basic salary according to the importance of the jobs. Exceptionally high performances have been rewarded with exceptionally high pay. In addition to technical knowledge, the importance of foreign languages has come into view. However, it is important to emphasize that, apart from key jobs (managers, specialists, etc.), local wage earnings are far below the levels available in the Western European labor market. For average payouts, the differences are 2-3 times (Average, EU; 2018), while these differences are "in the EU Member States ranged from EUR 261 to EUR 1999 per month in July 2018" (Minimum wage statistics, 2018).

The human resource management practices of organizations operating in the Central and Eastern European region have changed significantly since the change of regime - influencing factors varying from country to country and driven by incentive forces (Morley, 2008). Many of the common features of the forty-year-long socialist era that dominated the management of people's issues in many respects, have still had an impact even after more than two decades of transformation on today's HR practices - many believe, including the authors of this contribution.

Benchmarking is the process of identifying the highest standards of excellence for products, services, or processes, and then making the improvements necessary to reach those standards commonly called "best practices". Benchmarking is not just competitive analysis or number crunching, nor is it spying, espionage or stealing. It is a process to establish the ground for creative breakthroughs (Greengard, 1995). Benchmarking has become increasingly important, as organizations strive to compete globally by improving quality and reducing costs (Brillinger, 2001).

Benchmarking contributes to an organization's ability to attain a competitive position by monitoring industry best practices and determining measures of productivity. A further benefit is that self-analysis required by benchmarking encourages the identification of more efficient ways of operating. Benchmarking, by monitoring how other organizations function, offers alternatives to an organization's current business practices and, thus, can assist the performance of the organization. However, benchmarking is not without disadvantages. The changes needed to implement benchmarking require a great deal of teamwork, commitment, an objective focus on the issues concerned, and the willingness and ability on the part of the organization, and individuals, to change. It can also be expensive and difficult to implement. Further, the use of the wrong approach to benchmarking can be counter-productive for the organization or organizations involved and can ultimately undermine an organization's benchmarking efforts (Rodwell, Lam \& Fastenau, 2000) The complexity of benchmarking the human capital strategies of others due to higher barriers to imitation than those of product innovations has led many organizations to ignore the HR function (Huang, Roy, Ahmed, Heng \& Lim, 2002).

Benchmarking HR practices serves a number of purposes. First, it enables a company to calibrate how it is delivering HR practices. By looking at how other organizations are accomplishing tasks and responsibilities, a company can audit itself and identify areas where practices are within or outside a given norm. Second, benchmarking enables a company to learn from others' successes and mistakes. Building a continuous improvement mentality has become an important goal for many organizations in the last decade; benchmarking can open minds and create a climate in which active learning is encouraged. Third, benchmarking can be used as a tool for creating the motivation to change (Glanz \& Daily, 1992).

\section{Research methodology}

This current research is based on the research data of Cranfield Network of International Human Resources Management (Cranet). Cranet was established in 1989, and is now a collaboration of more than 40 universities and business schools, representing different countries from all over the world (Mayrhofer, 1998).

The Cranet Research methodology compared to the beginning (Brewster, Hegewisch \& Lockhart, 1991; Brewster, 1994) has not changed significantly until today, but rather expanded and enlarged. The research is based on the Cranet international research questionnaire and contains over 60 questions. The questionnaire, which is used world-wide, comprises seven main sections: 
1. The first section investigates the main characteristics of the Human Resource Management (HRM) department of the organizations surveyed;

2. The second examines resourcing practices;

3. The third deals with issues relating to employee development;

4. The fourth surveys the methods used in compensation and benefits practices;

5. The fifth looks for answers to questions of employee relations within the organization and the existence and forms of communication with employees;

6. The sixth features general questions on organizational data;

7. The seventh records personal information on the respondent. (Cranet, 2011)

In this paper, the authors analyze the data of the 2004-2005, 2008-2010 and 2014-2016 survey rounds. In our analysis, we will show country data in the following grouping:

1. Global cluster (Glob): This sample contains all respondents from the Cranet surveys at three different times, a very heterogeneous population. Nearly all continental European countries, AngloSaxon respondents from close and far parts of the world, and an increasing number of Asian countries can be found in it.

2. Former Eastern Bloc countries (CEE): This is a breakdown of countries in each country or successor that can be classified as "Old Eastern Bloc" or, in other words, Socialist countries. Six of the eight CEE countries in the Cranet sample are six EU members and one candidate. It is only Russia that is not part of this socio-economic form.

3. Global clustering without the countries of the "Old Eastern Bloc" (non-CCE countries). This group does not include the so-called "Former socialist countries" indicated in the previous subsection.

The number of respondent organizations in the three surveys and their distribution by country group is shown in Table 1.

Table 1 Number of respondent organizations

\begin{tabular}{c|c|c|c|c|c|c|c|c}
\hline \multicolumn{2}{c|}{$2004-2005$} & \multicolumn{3}{c|}{$2008-2010$} & \multicolumn{3}{c}{$2014-2016$} \\
\hline Glob & $\begin{array}{c}\text { Non } \\
\text { CEE }\end{array}$ & $\begin{array}{c}\text { CE } \\
\text { E }\end{array}$ & Glob & $\begin{array}{r}\text { Non } \\
\text { CEE }\end{array}$ & CEE & Glob & $\begin{array}{r}\text { Non } \\
\text { CEE }\end{array}$ & CEE \\
\hline 7809 & $\begin{array}{r}698 \\
n\end{array}$ & 826 & 6415 & $\begin{array}{r}521 \\
n\end{array}$ & 120 & 6800 & 506 & 173 \\
\hline
\end{tabular}

\begin{tabular}{c|c|c|c|c|c|c|c|c}
\hline $100 \%$ & $89 \%$ & $11 \%$ & $\begin{array}{r}100 \\
n\end{array}$ & $81 \%$ & $19 \%$ & 100 & $74 \%$ & $26 \%$ \\
\hline \multicolumn{1}{c}{ Source: Primary research by the authors }
\end{tabular}

The number of respondents representing the Non-CEE region has declined steadily, more and more organizations have joined the survey in the CEE region: the number of participants in the first and last few years has more than doubled.

Even more significant growth can be seen in the case of domestic organizations, where the number of participants in the third survey is nearly five times higher than that of the first respondents. Among the organizations, business and publicsector representatives are equally represented.

Human resources activities, that is, HR work has long been considered as women's occupations in the countries of Central and Eastern Europe. This can also be seen in our sample, in all three study periods. The difference is most prominent in the research period of 2004-2005: in the sample of global and non-CEE countries, the number of male respondents - both in the private and public sectors - is much higher than in the Central- European countries (Poór, Karoliny, Kovács \&Illés, 2018).

\section{Research results}

In the following section, we will analyze the similarities and differences of four different HR characteristics among the variables indicated without the need for completeness as follows:

1. availability of HR departments and HR services,

2. strategic importance of HR functions,

3. budget of training and development,

4. influences of Trade Unions.

The anticipated and experienced strengthening of the HR function and the strategic role, organizational influence, reputation, integration of the HR leader responsible for HR professional aspects at the beginning of the 21 st century is a fundamental element of many researches (Guzman, Neelankavil \& Sengupta, 2011; Ulrich \& Grochowski, 2018).

The results of the analysis on the availability of HR organizations are presented in Table 2., show that in terms of the global sample (Glob), all respondent organizations have a ratio of at least 80 $90 \%$ of organizations / institutions with independent HR or HR support. 
Table 2 Proportion of availability of HR departments or services (in \%)

\begin{tabular}{l|c|c|c|c|c|c|c|c|c}
\hline & \multicolumn{3}{|c|}{$2004-2005$} & \multicolumn{3}{|c|}{$2008-2010$} & \multicolumn{3}{|c}{$2014-2016$} \\
\cline { 2 - 10 } & Glob & $\begin{array}{l}\text { Non } \\
\text { CEE }\end{array}$ & CEE & Glob & $\begin{array}{l}\text { Non } \\
\text { CEE }\end{array}$ & CEE & Glob & $\begin{array}{l}\text { Non } \\
\text { CEE }\end{array}$ & CEE \\
\hline Private sector & 90,8 & 91,2 & 87,6 & 85,2 & 91,0 & 63,3 & 92,8 & 95,9 & 84,5 \\
\hline Public sector & 89,6 & 90,1 & 84,2 & 80,9 & 83,7 & 70,1 & 84,7 & 88,9 & 74,3 \\
\hline $\begin{array}{l}\text { All } \\
\text { responding } \\
\text { organizations }\end{array}$ & 90,5 & 90,9 & 87,4 & 83,7 & 88,5 & 65,1 & 90,7 & 93,9 & 81,6 \\
\hline
\end{tabular}

In terms of the global sample (Glob), all respondent organizations have a ratio of at least 80 $90 \%$ of organizations / institutions with independent HR or HR support. Global values, however, show a definite temporal fluctuation alongside a high level. At the beginning of the millennium, the $90 \%$ ratio is just below $84 \%$ in the first years of the 2008-2009 crisis, and then in the 3 rd round of our research surveys, it rises above $90 \%$. The downturn in the CEE region - and above all in the competitive sector - is remarkably high, reflecting the sensitivity of the HR area to changes in the economic situation of companies in this region.
According to our research, the HR leader (or person in charge of HR) is globally (Glob) at the beginning of the evaluated period (2004-2005) more than half of the respondents, and later more than $60 \%$ - represents HR function at the top level of the organizational hierarchy, usually a member of senior management (Nanzin \& Hussain, 2016; Trullen Stirpe, Bonache \&Valverde, 2016). According to strategic importance of HR function in non-CEE countries, we were able to establish stronger, while in the CEE region we were able to identify weaker integration.

In general, it has to be pointed out that the years following the crisis have also brought about changes in corporate training. There is a consensus that in order to achieve organizational success it is important that training should have to be an impact on the performance of the company (Chikán et al., 2011).

The data on the importance of training development (budget of training and development) are presented in Table 3 .

Table 3 Proportion of T\&D expenditure in annual wage cost (\%)

\begin{tabular}{c|r|r|r|r|r|r|r|r|r}
\hline $\begin{array}{c}\text { Proportion of T\&D } \\
\text { expenditure in annual } \\
\text { wage cost }\end{array}$ & \multicolumn{3}{|c|}{$2004-2005$} & \multicolumn{3}{|c|}{$2008-2010$} & \multicolumn{3}{|c|}{$2014-2016$} \\
\cline { 2 - 10 } & Glob & $\begin{array}{r}\text { Non } \\
\text { CEE }\end{array}$ & CEE & Glob & $\begin{array}{r}\text { Non } \\
\text { CEE }\end{array}$ & CEE & Glob & $\begin{array}{r}\text { Non } \\
\text { CEE }\end{array}$ & CEE \\
\hline $0 \%$ & 18,8 & 1,0 & 3,2 & 6,5 & 3,3 & 16,5 & 3,8 & 3,7 & 4,2 \\
\hline $1-2 \%$ & 40,4 & 49,7 & 48,5 & 44,6 & 45,8 & 40,7 & 45,6 & 43,6 & 51,0 \\
\hline $3-5 \%$ & 25,5 & 36,1 & 34,8 & 27,7 & 29,5 & 22,1 & 30,7 & 31,5 & 28,6 \\
\hline $6-10 \%$ & 10,6 & 9,4 & 9,5 & 12,4 & 12,4 & 12,5 & 13,6 & 13,9 & 12,9 \\
\hline Above 10\% & 4,8 & 3,9 & 4,0 & 8,8 & 9,0 & 8,2 & 6,2 & 7,3 & 3,4 \\
\hline Total & 100,0 & 100,0 & 100,0 & 100,0 & 100,0 & 100,0 & 100,0 & 100,0 & 100,0 \\
\hline
\end{tabular}

Source: Primary research by the authors

The importance of training has greatly increased in the last 10-12 years globally, and with this, the proportion of labor costs related to the development of labor training has been shifted upwards. There are no major differences in territorial comparisons, and recent survey data show that respondents in non-CEE countries are moving slightly towards higher rates compared to CEE countries in terms of training costs relative to wage costs. At the same time, it is important to emphasize that in the period 2008-2010, the proportion of responding organizations that have lowered their training costs to $0 \%$ has been greatly increased in the CEE countries, i.e. no T\&D funds have been spent on this (16.5\% in 2004). From $3.2 \%$ in 2005 to 2005 ), and it is also interesting to note that the share of over $10 \%$ has just jumped over this period (from $4 \%$ to $8.2 \%$ ). This extreme evolution is probably due to the difference in composition of responding organizations.

Since the marked separation of employee and owner interests (see Carrell \& Heavrin, 2014 for details on its formation), it is a natural fact that there are different interests of the owners and employees (László, 2010).Generally speaking, CEE region is in a special situation. The role of trade unions significantly diminished after compulsory trade union membership was abolished in the region (Poór et al, 2017).There are, of course, differences between countries, e.g., the unionization of workers employed by 
multinationals is especially low in Eastern Europe (Tóth, 1998).

Due to Cranet research at the global level (Glob), unionization level gradually decreased from an initial $39.2 \%$ to $33.5 \%$ by $2008-10$ and then to $31.7 \%$ by $2014-16$. Looking at CEE countries, it can be concluded that the level of unionization decreased from $32.3 \%$ in the first survey period (2004-2005) to $23.8 \%$ in $2014-16$. In some CEE countries (i.e. Hungary), we have experienced a much greater decline than the indicated values.

\section{Conclusion}

From our non-comprehensive analysis, we could highlight the following important similarities and differences.

It is clear from our analysis that the practice of CEE organizations relying on HR specialists is less characteristic of other regions. The initial lag of our CEE region in this area was maintained for the second century of the century. The proportion of male and female HR employees in the three examined periods also did not change significantly. It can be stated, however, that in the CEE region, this area is a position occupied by female employees. In addition to the many similarities and differences in the strategic importance of HR work, it is important to emphasize that the role of line management is crucial in the CEE region, in other parts of the world.

With respect to other HR characteristics, the direction of change in each region is the decline. These included responses to the weakening of trade union organization and the decline in their influence. This weakening was the largest in the CEE region.

Our studies based on longitudinal and international comparisons therefore show that although the CEE and the domestic HR practices of single CEE countries in the first two decades of the 21 st century have brought about a variety of changes, their deviations from different regions of the world, as well as their solutions, prevailed as well. All of them reinforce the opinion of researchers (Brewster et al., 2018) who, on the one hand, deal with the views on the univerzalisation of $\mathrm{HR}$, and on the other hand, emphasize the role of external (institutional and cultural) factors in pointing-out the context-specific nature of HR.sm

\section{References}

Amable, B. (2003). The Diversity of Modern Capitalism, Oxford: Oxford University Press. https://doi.org/10.1093/019926113X.001.0001

Amstrong, M. \& Taylor, S. (2017). Amstrong's handbook of Human Resource Management Practice. $\left(14^{\text {th }}\right.$ ed.) London: KoganPage.

Average Salaries in European Union. (2018). Average Salary in European Union 2018, Retrived June 3, 2018, from https://www.reinisfischer.com/average-salaryeuropean-union-2018.

Brewster, C. (1994). European HRM: reflection of, or challenge to, the American concept? In: Kirkbridge, $P$. (ed.). Human Resource Management in Europe. London: Routledge.

Brewster, C., Hegewisch, A., \& Lockhart, T. (1991). Researching Human Resource Management: The Methodology of the Price Waterhouse-Cranfield Project on European Trends. Personnel Review, (20) 6, 36-40. https://doi.org/10.1108/EUM0000000000804

Brewster, C., Morley, M., Buciuniene, I. (2010). The reality of human resource management in Central and Eastern Europe. Baltic Journal of Management, 5 (2), 145-155. https://doi.org/10.1108/17465261011045098

Brillinger, R. (2001). Best practices: human resources benchmarking.Canadian HR Reporter, 14(12), 12.

Cakrt, M. (1993). Management education in Eastern Europe: Toward mutual understanding. Academy of Management Executive, 7 (4), 63-68. https://doi.org/10.5465/ame.1993.9503103214

Carrell, M. \&Heavrin, C. (2014). Labor Relations \& Collective Bargaining Private and Public Sectors. Edinburgh Gate: Pearson Education Limited.

Chikán, A., Czakó, E., Zoltayné Paprika, Z., Antal, Z., Balaton, K., Demeter, K. \&Hortoványi, L. (2011). Corporate Competitiveness Rapid Report Crisis on the Results of the 2009 Survey. (In Hungarian) Budapest, CorvinusEgyetem.

Cranet Survey on Comparative Human Resource Management - International Executive Report 2011. (2011). Cranfield: Cranet.

Cvetanović, S., Despotović, D., \& Milovanović, G. (2018). Foreign direct investments as a source of financing of economic development of Western Balkan Countries. Ekonomika, 64(4), 17-28. https://doi.org/10.5937/ekonomika1804017C

Erutku, C. \&Vallee, L. (1997). Business start-ups in today's Poland: who and how? Entrepreneurship and Regional Development, 9, 113-126. https://doi.org/10.1080/08985629700000006

Glanz, E. , Daily L. (1992) Benchmarking. Human Resource Management, Spring 1992, 31 (1\&2), 9-20. https://doi.org/10.1002/hrm.3930310102

Greengard, S. (1995). Discover best practices from benchmarking.Personnel Journal, November.

Guzman, G. M.,Neelankavil, J. P. \& Sengupta, K. (2011). Human resources roles: ideal versus practiced: a crosscountry comparison among organizations in Asia. The International Journal of Human Resource Management. 22 (13), 2665-2682. https://doi.org/10.1080/09585192.2011.560865 
Hall, P. \& Soskice, D. (2001). An Introduction to the Varieties of Capitalism, in P. Hall and D. Soskice (eds), Varieties of Capitalism: The Institutional Basis of Competitive Advantage, Oxford: Oxford University Press.

https://doi.org/10.1093/0199247757.001.0001

Hancke, B., Rhodes, M. \&Thatcher, M. (2007). Introduction, in B. Hancke, M. Rhodes and M. Thatcher (eds), Beyond varieties of capitalism: conflict, contradiction, and complementarities in the European economy, Oxford: Oxford University Press. https://doi.org/10.1093/acprof:oso/9780199206483.001. $\underline{0001}$

Héder, M., Szabó, S., \& Dajnoki, K. (2018). Effect of labour market changes on HR functions. Anali Ekonomskog fakulteta u Subotici, (39), 123-138. https://doi.org/10.5937/AnEkSub1839123H

Huang G.Z.D., Roy H.M., Ahmed Z.U., Heng J.S.T., Lim J.S.T. (2002) Benchmarking the human capital strategies of MNCs in Singapore. Benchmarking: An International Journal, 9(4), 357-373. https://doi.org/10.1108/14635770210442699

Kazlakauiste, R., Buciunine, I., Poór, J., Karoliny, Z., Alas, R., Kohont, A. and Szlávicz, Á. (2013). Human Resource Management in the Central and Eastern European Region, in E. Parry, E. Stavrou and M. Lazarova (eds), Global Trends in Human Resource Management, London: .Palgrave-Macmillan. https://doi.org/10.1057/9781137304438 6

Kordić, N., \& Milićević, S. (2018). Human resources in the hotel industry of Serbia. Hotel and Tourism Management, 6(1), 93-103. https://doi.org/10.5937/menhottur1801093k

László, Gy. (2010). Ay alkalmazotti kapcsolatok rendszere (The system of industrial relations) In Karoliny, M. \& Poór, J. (eds.) Human Resource Managemenet Handbook. (In Hungarian) Budapest: Complex .401445.

Lewis, P. C. (2005). How the East was won. New York: Palgrave Macmillan. https://doi.org/10.1057/9780230503885

Mathias, L.M., Jackson, H.J., Valentine, R.S. Meglich, A.P. (2017). Human Resource Management. (15 th edition) Boston: CENGAGE Learning.

Mayrhofer, W. (1998). Between market, bureaucracy and clan: Coordination and control mechanismsinthe Cranfield Network on European Human Resource Management (Cranet-E). Journal of Managerial Psychology, (13) 3, 241- 258. https://doi.org/10.1108/02683949810215057

Minimum wage statistics (2018). Eurostat Statistics explained. Retrived December 22, 2018, from https://ec.europa.eu/eurostat/statisticsexplained/index.php/Minimum_wage_statistics

Morley, M. J. (ed.) (2008). Managing Human Resources in the Transition Economies of Central and Eastern Europe. Global HRM Series, Lonodon: Routledge.

Morley, M., Poór, J., Heraty, N., Alas, R., \&Pocztowski, A. (2016). Developments in Human Resource Management in Central and Eastern Europe in Comparative Perspective. In Dickmann, m., Brewster, C., Sparrow, P. (eds) Contemporary HR Issues in Europe. New York: Routledge.
Nanzin, H. \& Hussain, M. (2016). Strategic value contribution role of HR. Vision. 20 (2), 135-128. https://doi.org/10.1177/0972262916637274

Nica, E. (2018). Will robots take the jobs of human workers? Disruptive technologies that may bring about jobless growth and enduring mass unemployment. Psychosociological Issues in Human Resource Management, 6(2), 56-61. https://doi.org/10.22381/PIHRM6220184

Pearce, J. L. (1991). From socialism to capitalism: the effects of Hungarian human resources practices.Academy of Management Executive, November, 5 (4), 75-89. https://doi.org/10.5465/ame.1991.4274753

Perić, G., Gašić, M., Stojiljković, M., \& Nešić, I. (2018). The impact of employee satisfaction on the tourist satisfaction with the services of spa tourism. Economics of Agriculture, 65(2), 617-632. https://doi.org/10.5937/ekoPolj1802617P

Pocztowski, A. (2011). Human Resource Management in Transition- The Polish Case, Warszawa: OficynaWolters Kluwer Business Publishing House.

Poór, J. (2008). Human Resource Management in Hungary. In Morley, M. J. (ed.) Managing Human Resources in the Transition Economies of Central and Eastern Europe. London: Routledge.Poór J., Karoliny M-né., Kovács I. \&lllés B.Cs. (2018). HR Practice - Similar and Different Trend in Human Resource Management on Global, Regional and Local Levels. (In Hungarian) Budapest: Wolters Kluwer.

Popescu, G. H. (2018). Participation in the sharing economy: Labor, exchange, and consumption. An empirical analysis. Journal of Self-Governance and Management Economics, 6(1), 122-127. https://doi.org/10.22381/JSME6120185

Radivojević, V., Kahrović, E., \& Krstić, M. (2019). Population skills as an indicator of European countries competitiveness in the modern economy. Vojno delo, 71(5), 105-116. https://doi.org/10.5937/vojdelo1905105R

Rodwell J.J., Lam J., Fastenau M. (2000). Benchmarking HRM and the benchmarking of benchmarking: Best practices from outside the square in the Australian finance industry. Employee Relations, 22(4), 356-374. https://doi.org/10.1108/01425450010372619

Slavković, A., \& Slavković, V. (2019). The importance of training in contemporary organizations. Hotel and Tourism Management, 7(2), 115-125. https://doi.org/10.5937/menhottur1902115S

Stuken, T., \& Korzhova, O. (2019). Strategic personnel management: Context of retirement age reform in Russia. Strategic Management, 24(4), 21-27. https://doi.org/10.5937/StraMan1904021S

Trullen, J., Stirpe, L., Bonache, J. \&Valverde, M. (2016). The HR department's contribution to line managers' effective implementation of HR practices. Human Resource Management Journal, 26 (4), 449-470. https://doi.org/10.1111/1748-8583.12116

Ulrich, D. \&Grochowski, J. (2018). Auditing the Effectiveness of your HR Department. Retrived April 28, 2018, from https://rbl.net//blog/post/auditing-theeffectivessness-of-your-hr-department 
Whitley, R. (1999). Divergent Capitalisms: The Social

Structuring and Change of Business Systems, Oxford:

Oxford University Press.

\section{$\triangle$ Correspondence}

\section{Agneš Slavić}

University of Novi Sad Faculty of Economics Subotica

Segedinski put 9-11, 24000 Subotica, Serbia

E-mail: slavica@ef.uns.ac.rs 